\title{
PENGARUH MODEL PEMBELAJARAN THE POWER OF TWO TERHADAP HASIL BELAJAR BIOLOGI PESERTA DIDIK
}

\section{THE INFLUENCE OF THE POWER OF TWO LEARNING MODEL ON THE STUDENTS' BIOLOGY LEARNING OUTCOMES}

\author{
Ainul Uyuni Taufiq1), Ummul Hasanah2) \\ 1,2)Fakultas Tarbiyah dan Keguruan Universitas Islam Negeri Alauddin Makassar \\ ainul.uyuni@uin-alauddin.ac.id ${ }^{1}$,, ummul.hasanah@uin-alauddin.ac.id²)
}

\begin{abstract}
Abstrak
Penelitian ini bertujuan untuk mengetahui hasil belajar biologi peserta didik sebelum dan setelah menggunakan model pembelajaran tipe the power of two serta pengaruhnya terhadap hasil belajar. Jenis penelitian yang digunakan adalah penelitian eksperimen. Populasi penelitian ini adalah seluruh peserta didik kelas VIII MTs AsShalihin Gowa sebanyak 64 orang. Sampel penelitian ini adalah kelas VIII B sebanyak 32 orang. Instrumen penelitian yang digunakan adalah tes hasil belajar biologi. Berdasarkan hasil penelitian diperoleh bahwa hasil belajar biologi peserta didik sebelum menggunakan model pembelajaran tipe the power of two berada pada kategori cukup dengan nilai ratarata hasil belajar sebesar 62,23. Namun, setelah menggunakan model pembelajaran tipe the power of two berada pada kategori tinggi dengan nilai rata-rata hasil belajar sebesar 78,81. Dapat disimpulkan bahwa penerapan model pembelajaran the power of two berpengaruh dalam meningkatkan hasil belajar peserta didik pada mata pelajaran biologi di kelas VIII MTs As-Shalihin Gowa.
\end{abstract}

Kata Kunci: model pembelajaran the power of two, hasil belajar

\begin{abstract}
This study aims to determine student biology learning outcomes before and after using the learning model of the power of two and its effect on learning outcomes. The type of research used is experimental research. The study population was all students of class VIII MTs AsShalihin Gowa as many as 64 people. The sample of this research is class VIII B as many as 32 people. The research instrument used was a biology learning achievement test. Based on the results of the study, it was found that the biology learning outcomes of students before using the power of two learning model were in the sufficient category with an average value of learning outcomes of 62.23. After using the power of two learning model is in the high category with an average value of learning outcomes of 78.81. It can be concluded that using the power of two learning model has an effect on improving biology learning outcomes of students in class VIII MTs As-Shalihin Gowa.
\end{abstract}

Keywords: the power of two learning model, learning outcomes

How to Cite: Taufiq, A. U. \& Hasanah, U. (2020). Pengaruh model pembelajaran the power of two terhadap hasil belajar biologi peserta didik. Al asma: Journal of Islamic Education, 2(1), 111-120. 


\section{PENDAHULUAN}

Dalam keseluruhan proses pendidikan di sekolah, kegiatan belajar merupakan kegiatan yang paling utama. Ini berarti bahwa berhasil tidaknya pencapaian tujuan pendidikan banyak bergantung kepada bagaimana proses belajar yang dialami oleh siswa sebagai anak didik. Pendidikan merupakan tempat untuk mencetak manusia menjadi manusia yang sebenarnya, manusia yang cerdas, manusia yang bermartabat, berakhlak mulia, manusia yang kreatif dan kritis. Mengingat hal tersebut, dunia pendidikan khususnya lembaga pendidikan formal menghadapi tantangan yang berat. Tantangan tersebut adalah lembaga pendidikan harus mampu menyiapkan kualitas sumber daya manusia yang handal (Purwanto, 2009).

Pembelajaran efektif menuntut keterlibatan siswa secara aktif karena mereka merupakan pusat kegiatan pembelajaran dan pembentukan kompetensi. Siswa harus didorong untuk menafsirkan informasi yang disajikan oleh guru sampai informasi tersebut dapat diterima oleh akal sehat. Dalam pelaksanaannya, hal ini memerlukan proses pertukaran pikiran, diskusi, dan perdebatan dalam rangka pencapaian pemahaman yang sama terhadap materi standar yang harus dikuasai siswa. Menurut Kenneth D. More dalam Rusman (2010), ada tujuh langkah dalam mengimplementasikan pembelajaran efektif yaitu: (1) perencanaan; (2) perumusan tujuan/kompetensi; (3) pemaparan perencanaan pembelajaran kepada siswa; (4) proses pembelajaran dengan menggunakan berbagai strategi (multistrategi); (5) evaluasi; (6) menutup proses pembelajaran; dan (7) follow up/tindak lanjut.

Salah satu cara untuk mewujudkan keberhasilan kegiatan belajar mengajar adalah pemilihan model pembelajaran yang tepat dan efisien, model pembelajaran didefinisikan sebagai cara yang digunakan guru, yang dalam menjalankan fungsinya merupakan alat untuk mencapai tujuan pembelajaran (Trianto, 2007).

Pembelajaran biologi yang oleh sebagian besar siswa masih dirasakan sulit, tentu sangat membutuhkan sikap guru dalam mengatasinya. Pemilihan model pembelajaran yang kurang tepat mengakibatkan efektivitas pembelajaran tidak tercapai. Indikasi ini dapat terlihat dengan menurunnya hasil belajar siswa. Hal ini juga dialami siswa di MTs As-Shalihin Gowa. Hasil observasi dan wawancara bersama guru mata pelajaran biologi diperoleh data bahwa pada saat pembelajaran berlangsung banyak siswa yang mengantuk, merasa bosan, main-main, dan tidak memperhatikan materi sehingga pada saat diberi umpan balik banyak yang mengalami kesulitan memahami konsep pembelajaran biologi. Hal ini disebabkan oleh beberapa faktor antara lain materi biologi umumnya cakupannya sangat banyak, adanya keterbatasan waktu sehingga siswa tidak memiliki kesempatan untuk melibatkan diri dalam pembelajaran, interaksi hanya terjadi satu arah sehingga pembelajaran cenderung hanya berpusat pada guru.

Saat ini banyak dikembangkan berbagai model pembelajaran kooperatif. Model yang sesuai untuk suatu materi biologi dan siswa tertentu tampaknya masih perlu dikaji. Dalam penelitian ini penulis menggunakan pembelajaran kooperatif tipe the power of two karena model pembelajaran ini masih jarang digunakan dalam proses pembelajaran biologi di sekolah-sekolah. Selain itu, model pembelajaran ini merupakan salah satu cara terbaik untuk meningkatkan belajar lebih aktif dengan pemberian tugas belajar yang dilakukan dalam kelompok-kelompok kecil siswa. 
Belajar dilakukan untuk mengusahakan adanya perubahan perilaku pada individu yang belajar. Perubahan perilaku itu merupakan perolehan yang menjadi hasil belajar. Jadi hasil belajar menurut Winkel dalam Purwanto (2009) adalah perubahan yang mengakibatkan manusia berubah dalam sikap dan tingkah lakunya.

Menurut Simanjuntak (2011) bahwa identifikasi terhadap kemampuan anak dalam proses belajar dapat diukur melalui tes hasil belajar. Lebih lanjut dikatakannya dalam kurikulum sudah dicantumkan target ketercapaian dari pembelajaran itu sendiri, sehingga untuk mencapainya dapat diukur melalui tes hasil belajar.

Suherman, dkk (2001:71) mengemukakan bahwa hasil belajar biologi perlu diusahakan secara bersifat menyeluruh, dalam arti meliputi langkah kerja dan hasil kerja. Cara yang dapat dilakukan dalam melihat hasil belajar meliputi: (1) pengamatan terhadap siswa sewaktu bekerja, (2) mendengarkan dengan cermat apa yang diperbincangkan siswa, (3) mendengarkan secara cermat pendapat siswa, (4) menganalisis hasil kerja siswa, dan (5) tes.

Diantara model-model pembelajaran, model pembelajaran kooperatif merupakan model pembelajaran yang unik, karena model pembelajaran kooperatif suatu struktur tugas dan penghargaan yang berbeda dalam mengupayakan pembelajaran siswa. Struktur tugas itu menghendaki siswa untuk bekerja bersama dalam kelompok-kelompok kecil. Model pembelajaran kooperatif tumbuh dari suatu tradisi pendidikan yang menekankan berfikir dan latihan bertindak demokratis, pembelajaran aktif, perilaku kooperatif, dan menghormati perbedaan dalam masyarakat multi budaya.

Menurut Suprijono (2012) pembelajaran kooperatif adalah konsep yang lebih luas meliputi semua jenis kerja kelompok termasuk bentuk-bentuk yang lebih dipimpin oleh guru atau diarahkan oleh guru. Secara umum pembelajaran kooperatif dianggap lebih diarahkan oleh guru, di mana guru menetapkan tugas dan pertanyaan-pertanyaan serta menyediakan bahan-bahan dan informasi yang dirancang untuk membantu siswa menyelesaikan masalah yang dimaksud. Guru biasanya menetapkan bentuk ujian tertentu pada akhir tugas.

Berdasarkan hal tersebut, pembelajaran kooperatif didefenisikan sebagai suatu sistem pembelajaran dimana siswa diberi kesempatan untuk menyelesaikan masalah, menyelesaikan suatu tugas atau mengerjakan sesuatu untuk mencapai tujuan bersama dalam suatu kelompok heterogen yang anggotanya empat sampai lima orang.

Silberman (2009), menyatakan salah satu cara terbaik untuk mengembangkan belajar yang aktif adalah memberikan tugas belajar yang diselesaikan dalam kelompok kecil siswa. Dukungan sejawat, keragaman pandangan, pengetahuan dan keahlian, membantu mewujudkan belajar kolaboratif yang menjadi satu bagian yang berharga untuk iklim belajar di kelas. salah satu diantaranya adalah pembelajaran tipe the power of two. model pembelajaran kooperatif tipe the power of two berarti menggabungkan dua kepala dalam hal ini adalah membentuk kelompok kecil, yaitu masing-masing siswa berpasangan. Kegiatan ini dilakukan agar munculnya suatu sinergi yakni dua kepala lebih baik dari satu. 
Menurut (Suprijono, 2012: 100) langkah-langkah pelaksanaan model pembelajaran kooperatif tipe the power of two ditampilkan pada Tabel 1.

Tabel 1. Model Pembelajaran Kooperatif dengan Tipe The Power of Two

\begin{tabular}{cl}
\hline Fase & \multicolumn{1}{c}{ Model Kooperatif The Power of Two } \\
\hline Fase 1 & Menyampaikan tujuan dan memotivasi siswa \\
Fase 2 & Menyajikan informasi \\
Fase 3 & Mengorganisasikan siswa kedalam kelompok belajar \\
Fase 4 & Membimbing kelompok bekerja dan belajar \\
& a. Ajukan satu atau lebih pertanyaan \\
& b. Berpikir individu \\
& c. Berpikir bersama dalam bentuk pasangan dan saling bertukar \\
& d. jawaban satu sama lain \\
Fase 5 5 & Presentasi jawaban baru \\
Fase 6 & Memberikan penghargaan
\end{tabular}

Model pembelajaran the power of two dapat berpengaruh terhadap hasil belajar kognitif siswa karena, model the power of two menuntut keaktifan siswa dalam memahami suatu materi dengan saling bertukar pikiran dengan teman, hal ini didukung oleh beberapa pendapat para ahli bahwa model pembelajaran ini di gunakan untuk mendorong pembelajaran kooperatif dan memperkuat penting dan manfaatnya sinergi, yaitu bahwa dua kepala sungguh lebih baik dari pada satu kepala. (Zaini, $2002: 26$ ).

Agar pelaksanaannya dapat menghemat waktu perlu adanya variasi-variasi yaitu menentukan pertanyaan tertentu untuk pasangan tertentu. Ini lebih baik daripada tiap pasangan menjawab semua pertanyaan (Silberman, 2009). Pada akhir setiap pertemuan, guru mengadakan evaluasi berupa kuis yang dikerjakan oleh siswa secara individu. Skor yang diperoleh siswa dalam evaluasi tersebut selanjutnya diproses untuk menentukan nilai perkembangan individu yang akan disumbangkan sebagai skor kelompok.

Model pembelajaran kooperatif tipe the power of two ini menekankan pada keaktifan siswa dengan melibatkan siswa secara aktif melalui diskusi mengenai jawaban dari pertanyaan- pertanyaan yang diberikan oleh guru dengan pasangannya. Dalam hal ini, siswa kelompok atas akan menjadi tutor bagi siswa kelompok bawah. Dalam proses tutorial ini, siswa kelompok atas akan meningkat kemampuan akademiknya karena memberi pelayanan sebagai tutor membutuhkan pemikiran lebih mendalam tentang hubungan ide-ide yang terdapat di dalam materi tersebut (Ibrahim, 2000).

Model pembelajaran kooperatif tipe the power of two berarti menggabungkan dua kepala. guru memberi siswa satu atau lebih pertanyaan yang membutuhkan refleksi dan pikiran, selanjutnya siswa diharapkan mampu memecahkan dengan cara berpasangan. Berdasarkan uraian diatas maka dilakukan penelitian dengan judul "Pengaruh Model Pembelajaran The Power of Two terhadap Hasil Belajar Biologi Peserta Didik" dengan tujuan untuk mengetahui hasil belajar biologi siswa sebelum dan setelah menggunakan model pembelajaran tipe the power of two, serta pengaruhnya terhadap hasil belajar. 


\section{METODE PENELITIAN}

Jenis penelitian ini adalah penelitian eksperimen. Penelitian ini menggunakan satu kelas, dilakukan dengan menggunakan model pembelajaran the power of two. Desain penelitian yang digunakan adalah pre test - post test one group design yang merupakan salah satu jenis quasi eksperimental design (eksperimen semu). Lokasi penelitian bertempat di MTs As-Shalihin Kabupaten Gowa, Sulawesi Selatan. Populasi penelitian ini adalah seluruh peserta didik kelas VIII MTs As-Shalihin Gowa sebanyak 64 orang. Sampel penelitian ini adalah kelas VIII B sebanyak 32 orang dengan teknik pengambilan sampel menggunakan teknik purposive sampling. Adapun instrumen yang peneliti gunakan adalah tes hasil belajar biologi. Tes hasil belajar biologi merupakan instrumen penelitian yang digunakan untuk mengukur tingkat penguasaan domain kognitif peserta didik setelah perlakuan. Pengolahan data dalam penelitian dengan analisis statistik meliputi analisis deskriptif dan analisis inferensial. Dalam penelitian ini peserta didik diberikan reward untuk menambah semangat belajar.

\section{HASIL PENELITIAN}

Berikut ini adalah tabel hasil belajar peserta didik sebelum menggunakan model pembelajaran The Power of Two:

Tabel 2. Persentase nilai hasil belajar peserta didik sebelum menggunakan model pembelajaran The Power of Two

\begin{tabular}{cccc}
\hline Interval & Frekuensi & Persentase (\%) & Kategori \\
\hline $85-100$ & 0 & 0 & Sangat Tinggi \\
$65-84$ & 11 & 34,37 & Tinggi \\
$55-64$ & 14 & 43,75 & Cukup \\
$35-54$ & 7 & 21,88 & Rendah \\
$0-34$ & 0 & 0 & Sangat Rendah \\
\hline Jumlah & 32 & 100 & \\
\hline
\end{tabular}

Dari tabel di atas dapat dilihat bahwa persentase skor pre test berada pada kategori rendah dengan persentase 21,88\%, kategori cukup dengan persentase 43,75\%, kategori tinggi dengan persentase $34,37 \%$ dan kategori sangat tinggi dengan persentase $0 \%$. Berdasarkan nilai rata-rata hasil belajar peserta didik sebesar 62,23 yang jika dimasukkan ke dalam tabel berada pada interval 55 - 64. Sehingga dapat dikatakan bahwa rata-rata hasil pre test peserta didik berada pada kategori cukup.

Tabel 3. Persentase nilai hasil belajar peserta didik setelah menggunakan model pembelajaran The Power of Two

\begin{tabular}{cccc}
\hline Interval & Frekuensi & Persentase (\%) & Kategori \\
\hline $85-100$ & 9 & 28,12 & Sangat Tinggi \\
$65-84$ & 22 & 68,75 & Tinggi \\
$55-64$ & 1 & 3,13 & Cukup \\
$35-54$ & 0 & 0 & Rendah \\
$0-34$ & 0 & 0 & Sangat Rendah \\
\hline Jumlah & 32 & 100 & \\
\hline
\end{tabular}


Dari Tabel 3 dapat dilihat bahwa persentase skor posttest berada pada kategori cukup dengan persentase 3,13\%, kategori tinggi dengan persentase $68,75 \%$ dan kategori sangat tinggi dengan persentase $28,12 \%$. Berdasarkan nilai rata-rata hasil belajar peserta didik sebesar 78,81 yang jika dimasukkan ke dalam tabel berada pada interval 61-80 sehingga dapat dikatakan bahwa rata-rata hasil post test peserta didik berada pada kategori tinggi.

Tabel 4. Distribusi Frekuensi dan Persentase hasil belajar peserta didik sebelum dan setelah menggunakan model pembelajaran The Power of Two

\begin{tabular}{cccccc}
\hline Interval & \multicolumn{2}{c}{ Frekuensi } & \multicolumn{2}{c}{ Persentase(\%) } & Kategori \\
& Pre test & Post test & Pre test & Post test & \\
\hline $85-100$ & 0 & 9 & 0 & 28,12 & Sangat Tinggi \\
$65-84$ & 0 & 22 & 0 & 68,75 & Tinggi \\
$55-64$ & 21 & 1 & 65.63 & 3,13 & Cukup \\
$35-54$ & 11 & 0 & 34.37 & 0 & Rendah \\
$0-34$ & 0 & 0 & 0 & 0 & Sangat Rendah \\
\hline Jumlah & 32 & 32 & 100 & 100 & \\
\hline
\end{tabular}

Persentase hasil belajar peserta didik pada pre test menunjukkan kategori rendah dengan persentase $21,88 \%$, kategori cukup dengan persentase $43,75 \%$, kategori tinggi dengan persentase $34,37 \%$ dari 32 peserta didik. Berdasarkan data tersebut dapat dikatakan bahwa kategori hasil belajar peserta didik pada pre test berada pada kategori cukup. Sedangkan persentase hasil belajar peserta didik pada post test menunjukkan kategori cukup sebesar 3.13\%, kategori tinggi sebesar 68.75\% dan sangat tinggi sebesar $28.12 \%$ dari 32 peserta didik. Berdasarkan data tersebut dapat dikatakan bahwa kategori hasil belajar peserta didik pada hasil post test berada pada kategori tinggi.

Berdasarkan hasil analisis deskriptif di atas, menunjukkan bahwa hasil belajar peserta didik setelah menggunakan model the power of two lebih tinggi jika dibandingkan dengan sebelum menggunakan model the power of two.

Selanjutnya berdasarkan hasil analisis statistik inferensial diperoleh nilai $t_{\text {hit }}=$ 22,17 dan nilai $t_{t a b}=2,04$. Dalam hal ini $t_{h i t}>t_{t a b}$ sehingga $H_{0}$ ditolak. Hal tersebut menunjukkan bahwa penggunaan model the power of two berpengaruh terhadap hasil belajar peserta didik dalam mata pelajaran biologi di kelas VIII MTs As-Shalihin Gowa.

Berdasarkan hasil analisis data yang diuraikan di atas, maka secara kuantitatif hasil penelitian menunjukkan penerapan model pembelajaran the power of two berpengaruh terhadap peningkatan hasil belajar biologi peserta didik MTs As-Shalihin Gowa.

\section{PEMBAHASAN}

\section{Hasil Belajar Peserta didik Sebelum Menggunakan Model Pembelajaran The Power of Two}

Hasil analisis data menunjukkan bahwa nilai rata-rata pre test peserta didik adalah 62,23 berada pada kategori cukup berdasarkan kriteria dari Badan Standar Nasional Pendidikan (BSNP), (Departemen Pendidikan Nasional, 2008). Dari hasil pengamatan sebelum peneliti menerapkan model pembelajaran the power of two, peserta didik terlihat tidak aktif dalam proses pembelajaran dan banyak peserta didik yang tidak fokus mengikuti pembelajaran. Hal ini terlihat dari adanya beberapa peserta didik yang keluar 
masuk kelas dan hanya bermain dengan temannya, tentunya situasi ini juga sangat mengganggu bagi peserta didik lain yang ingin fokus belajar. Dari data yang diperoleh pada saat pre test menunjukkan bahwa tidak ada peserta didik yang memperoleh nilai pada batas atau melebihi KKM (Kriteria Ketuntasan Minimal). KKM mata pelajaran IPA di MTs As-Shalihin adalah 75, sedangkan nilai tertinggi yang diperoleh peserta didik adalah 73,33 .

Rendahnya rata-rata nilai hasil Pre-test belajar peserta didik dikarenakan guru mengajar dengan metode tidak bervariasi, yang efeknya menjadikan peserta didik tidak dilibatkan secara keseluruhan dan terkadang masih banyak guru yang kurang memperhatikan tingkat psikologis dari peserta didik itu sendiri. Oleh karena itu terkadang ada peserta didik yang menganggap bahwa belajar bagaikan suatu pemaksaan kepada setiap orang untuk mengikutinya dan tidak hanya itu, jika kata belajar diganti dengan kata pelatihan atau kursus, maka otak pun akan mengeneralisasikan dan menyamakannya dengan belajar. Jadi, tetap saja orang yang mengikutinya menjadi orang yang enggan atau malas memperhatikan guru. Dampaknya peserta didik seringkali tidak antusias dalam mengikuti pelajaran, peserta didik sulit diatur karena merasa guru tidak memperhatikannya. Selain itu, peserta didik juga sulit fokus dan sulit mengerti. Dampak lain adalah peserta didik suka membolos. Persoalannya karena takut menghadapi pelajaran yang dianggap membosankan.

Hal ini sejalan dengan pendapat Slameto (2003) bahwa hasil belajar dipengaruhi oleh beberapa faktor, baik faktor dari dalam (faktor internal) maupun dari luar (faktor eksternal). Faktor internal adalah faktor jasmaniah, psikologis, dan faktor kelelahan (misalnya intelegensi, perhatian, minat, bakat, motif, kematangan, kesiapan) sedangkan yang termasuk faktor eksternal adalah faktor keluarga, faktor sekolah dan faktor masyarakat (misalnya guru, kurikulum, dan model pembelajaran). Sedangkan Bloom $(1982,11)$ dikutip oleh Djamaah Sopah $(2000,127)$, mengemukakan tiga faktor utama yang mempengaruhi hasil belajar, yaitu kemampuan kognitif, motivasi berprestasi, dan kualitas pembelajaran.

\section{Hasil Belajar Peserta didik Setelah Menggunakan Model pembelajaran the power of two.}

Hasil analisis data menunjukkan bahwa terjadi peningkatan hasil belajar peserta didik setelah diajar dengan menggunakan model pembelajaran the power of two. Nilai rata-rata peserta didik sebesar 78,81 berada pada kategori tinggi berdasarkan kriteria dari Badan Standar Nasional Pendidikan (BSNP), (Departemen Pendidikan Nasional, 2008). Hal ini menunjukkan peningkatan hasil belajar, dilihat dari perolehan nilai pre test atau nilai sebelum penerapan model pembelajaran the power of two adalah 62,23 berada pada kategori cukup.

Dengan melihat fakta yang ada bahwa nilai pre test peserta didik berada di bawah standar KKM maka penulis berusaha memberikan solusi dengan cara menerapkan salah satu model pembelajaran yaitu model pembelajaran the power of two, dengan harapan bahwa model ini dapat meningkatkan hasil belajar peserta didik. Model pembelajaran the power of two adalah model pembelajaran yang dipergunakan untuk mengaktifkan peserta didik. Model ini membagi peserta didik secara berpasangan, dimana setiap pasangan peserta didik ini akan bekerja sama secara aktif dalam proses pembelajaran. Jadi, model 
ini sangat cocok digunakan dalam pembelajaran karena dapat mengaktifkan peserta didik dan dapat menjadikan proses belajar peserta didik menjadi lebih menyenangkan.

Dengan penerapan model pembelajaran the power of two, hasil belajar peserta didik jadi meningkat. Hal ini terlihat dari sebanyak 18 orang peserta didik telah mencapai bahkan melewati batas nilai KKM. Peningkatan yang terjadi pada hasil belajar peserta didik disebabkan oleh penerapan pembelajaran model kooperatif tipe The Power of Two yang lebih bermakna. Hal ini sesuai dengan pernyataan (Johnson \& Johnson 1987; Slavin, 1983a) bahwa pembelajaran kooperatif adalah sebuah pendekatan untuk instruksi dimana peserta didik bekerja dalam kelompok kecil untuk membantu orang lain belajar.

Hal ini juga relevan dengan hasil penelitian Nurdin (2007: 80). Dalam hal ini masing-masing peserta didik membutuhkan teman dalam menyelesaikan tugas-tugas pembelajaran. Peserta didik yang kurang pandai merasa perlu bertanya pada yang lebih pandai, sebaliknya yang lebih pandai merasa berkewajiban untuk mengajari temannya begitupun dalam persentase seharusnya teman pasangannya harus memberikan kepercayaan kepada pasangannya yang kurang pandai. Sehingga pembelajaran menjadi lebih menyenangkan, jika pembelajaran menyenangkan maka peserta didik akan termotivasi untuk belajar dan hasil belajarnya pun dapat meningkat. Hal ini sejalan dengan hasil penelitian Fuhasari (2012) bahwa model pembelajaran kooperatif tipe The Power of Two dapat meningkatkan hasil belajar peserta didik karena cara belajar peserta didik melalui diskusi secara berpasangan.

\section{Pengaruh Penerapan Model Pembelajaran Tipe The Power of Two Terhadap Hasil Belajar Biologi Peserta didik.}

Hasil analisis dengan menggunakan uji $t$ diperoleh nilai $t_{\text {hit }}=22,17$ dan nilai $t_{\text {tab }}$ $=2,04$ dengan $d k=31$. Sehingga nilai $t_{\text {hit }}>t_{t a b}$ dengan demikian dan $H_{0}$ ditolak, serta dapat disimpulkan bahwa pemberian model pembelajaran the power of two berpengaruh dalam meningkatkan hasil belajar peserta didik pada mata pelajaran biologi di kelas VIII MTs As-Shalihin Gowa. Hal ini sejalan dengan hasil penelitian Ibrahim (2000: 7) bahwa dengan belajar kooperatif akan memperbaiki prestasi peserta didik atau tugas-tugas akademik penting lainnya serta akan memberi keuntungan baik pada peserta didik kelompok bawah maupun kelompok atas yang bekerja bersama menyelesaikan tugastugas akademis.

Tingkat keberhasilan pelaksanaan suatu proses pembelajaran dipengaruhi oleh banyak faktor, diantaranya adalah pemilihan model pembelajaran. Model pembelajaran kooperatif tipe The Power of Two ini menekankan pada keaktifan peserta didik dengan melibatkan peserta didik secara aktif melalui diskusi mengenai jawaban dari pertanyaanpertanyaan yang diberikan oleh guru dengan pasangannya. Dalam hal ini, peserta didik kelompok atas akan menjadi tutor bagi peserta didik kelompok bawah. Dalam proses tutorial ini, peserta didik kelompok atas akan meningkat kemampuan akademiknya karena memberi pelayanan sebagai tutor membutuhkan pemikiran lebih mendalam tentang hubungan ide-ide yang terdapat di dalam materi tersebut (Ibrahim, 2000).

Penerapan model pembelajaran kooperatif tipe the power of two berpengaruh terhadap peningkatan hasil belajar peserta didik. Hal ini dikarenakan dalam proses pembelajaran peserta didik aktif untuk belajar. Dalam proses pembelajaran di kelas VIIIB MTs As-Shalihin Gowa, peserta didik sangat antusias belajar, berdiskusi dengan temannya, 
mengerjakan tugas pada lembar kerja peserta didik, dan mempresentasikan hasil kerja mereka. Penelitian yang dilakukan oleh Fatkhurohman (2015) menjelaskan bahwa proses pembelajaran yang menggunakan model The Power of Two pada kelas VIIB berpengaruh positif terhadap hasil belajar peserta didik dan hasil belajarnya lebih baik dibandingkan hasil belajar peserta didik yang diajar dengan menggunakan model pembelajaran konvensional. Hal ini juga sejalan dengan penelitian Masri'ah (2016) bahwa Pembelajaran fiqih dengan menggunakan model pembelajaran the power of two and four mampu meningkatkan hasil belajar peserta didik saat pembelajaran baik secara individual maupun kelompok dari pra siklus, siklus I sampai siklus II setelah ada perbaikan pada tiap-tiap siklus. Hal ini tampak dari peningkatan nilai hasil belajar peserta didik yang teramati pada saat berlangsungnya proses belajar mengajar. Rata-rata hasil belajar peserta didik meningkat dari 66,20 pada pra siklus, 76,37 pada siklus I dan 86,89 pada siklus II. Dan ketuntasan klasikal belajar peserta didik juga mengalami peningkatan dari $48,27 \%$ pada pra siklus, siklus I, 68,96\% dan pada siklus II 93,10\%. Slameto (2010:36) menyatakan bahwa penerimaan pelajaran jika dengan aktivitas peserta didik sendiri, kesan itu tidak akan berlalu begitu saja, tetapi dipikirkan, diolah, kemudian dikeluarkan lagi dalam bentuk yang berbeda. Dengan menggunakan model pembelajaran kooperatif tipe The Power of Two diharapkan dapat meningkatkan belajar lebih aktif dengan pemberian tugas belajar yang dilakukan dalam kelompok kecil peserta didik.

\section{SIMPULAN}

Berdasarkan hasil penelitian dan pembahasan di atas maka diperoleh beberapa kesimpulan sebagai berikut: (1) Hasil belajar biologi peserta didik sebelum menggunakan model pembelajaran tipe The Power of Two berada pada kategori cukup dengan nilai ratarata hasil belajar peserta didik sebesar 62,23; (2) Hasil belajar biologi peserta didik setelah menggunakan model pembelajaran tipe The Power of Two berada pada kategori tinggi dengan nilai rata-rata hasil belajar peserta didik sebesar 78,81; (3) Berdasarkan analisis data dengan menggunakan uji $t$ diperoleh nilai $t_{\text {hit }}=22,17$ dan nilai $t_{t a b}=2,04$ dengan $d k=31$. Sehingga nilai $t_{h i t}>t_{t a b}$ dengan demikian dan $H_{0}$ ditolak, serta dapat disimpulkan bahwa pemberian model pembelajaran the power of two berpengaruh dalam meningkatkan hasil belajar peserta didik pada mata pelajaran biologi di kelas VIII MTs AsShalihin Gowa.

\section{DAFTAR PUSTAKA}

Depdiknas. (2008). Panduan Pengembangan Bahan Ajar. Jakarta: Direktorat Pembinaan SMA. Dirjen Mandikdasmen. Depdiknas.

Fatkhurohman, N. (2015). Pengaruh Model Pembelajaran Kooperatif Tipe The Power Of Two (Kekuatan Berdua) terhadap Hasil Belajar pada Pelajaran Matematika Materi Himpunan pada Siswa Kelas VII A MTs Miftahul Huda Bandung Tulungagung Tahun Pelajaran 2014/2015. Skripsi. Institut Agama Islam Negeri Tulungagung.

Fuhasari, H. (2012). Peningkatan Hasil Belajar IPA dengan Menerapkan Metode The Power of Two pada Siswa Kelas IV SD Negeri Trangsan 03 Gatak Sukoharjo Tahun Ajaran 2011/2012. Jurnal Pendidikan, (Online), (http://www.ums.ac.id, Diakses 24 September 2018). 
Ibrahim, M., Rachmadiarti, F., Nur, \& M., Ismono. (2000). Pembelajaran Kooperatif. Surabaya: UNESA

Masri'ah, S. (2016). Peningkatan Hasil Belajar Melalui Penerapan Strategi Pembelajaran The Power Of Two and Four Mata Pelajaran Fikih Materi Puasa di MTS Darul Ulum Ngaliyan Semarang. Jurnal Pendidikan Madrasah (Online), Volume 1, Nomor 2, November (http://ejournal.uinsuka.ac.id/tarbiyah/index.php/IPM/article/download/1212/1 $\underline{105}$, Diakses 14 Mei 2020).

Nur Wahidah. (2010). Keefektifan Penerapan Strategi Berpikir, Berbicara dan Menulis (BBM) Setting Kooperatif dalam Pembelajaran Matematika pada Siswa Kelas VII SMP Negeri 13 Makassar. Tesis. Tidak diterbitkan. Universitas Negeri Makassar.

Nurdin. (2007). Model Pembelajaran Matematika yang Menumbuhkan Kemampuan Metakognitif untuk Menguasai Bahan Ajar. Disertasi. Tidak diterbitkan. Universitas Negeri Surabaya.

Purwanto. (2009). Evaluasi Hasil Belajar. Yogyakarta: Pustaka Pelajar.

Rusman. (2010). Model-Model Pembelajaran: Mengembangkan Profesionalisme Guru. Jakarta: Rajawali Press.

Silberman. (2009). Pembelajaran The Power of Two, (Online). (http://www.scribd.com /doc31286550/Pembelajaran-the-Power-of-Two, Diakses, 23 September 2018).

Slameto. (2010). Belajar dan Faktor-faktor yang Mempengaruhinya. Jakarta: Rineka Cipta.

Sopah, D. (2000). Pengaruh Model Pembelajaran dan Motivasi Berprestasi terhadap Hasil Belajar. Jurnal Pendidikan dan Kebudayaan.

Suherman., Turmudi., Suryadi., Herman., Suhendra., Prabawanto., Nurjannah., \& Rohayati. (2001). Strategi Pembelajaran Matematika Kontemporer. Bandung: Jurusan pendidikan Matematika FMIPA UPI.

Suprijono, A. (2012). Cooperative Learning Teori dan Aplikasi PAIKEM. Yogyakarta: Pustaka Pelajar.

Trianto. (2007). Model-model Pembelajaran Inovatif. Jakarta: Grasindo.

Zaini Hisyam, dkk. (2002). Desain Pembelajaran di Perguruan Tinggi. Yogyakarta: CTSD 